\title{
ACESSO À JUSTIÇA, CURADORIA ESPECIAL E CUSTEIO DO PROCESSO VISTOS A PARTIR DO PECULIAR CASO DA (NÂO) CONCESSÁO DA GRATUIDADE DE JUSTIÇA AO RÉU CITADO FICTAMENTE
}

Suelen Tavares Gil

Membro do grupo de pesquisa "Jurisdição e Democracia: Interface entre a Linguagem e a Filosofia nas Decisóes Judiciais", da UFRN. Pesquisadora no projeto de extensão e pesquisa

"Cascudo JuriLab", da UFRN. Advogada.

suelengil@gmail.com

\section{RESUMO}

O Superior Tribunal de Justiça tem o entendimento majoritário de que a gratuidade de justiça não deve ser concedida ao réu citado fictamente e sob curadoria especial, o que implica um obste ao acesso à corte. Este estudo propõe a análise de decisões do STJ. Previamente, são levantadas duas hipóteses para a não concessão do benefício. A primeira seria a impossibilidade legal da concessáo do pedido de gratuidade de justiça apresentado pelo curador especial, e a segunda seria o uso de argumento econômico para se evitar despesas ao Judiciário. $\mathrm{Da}$ análise das decisóes, porém, não são verificadas as hipóteses, e sim a ausência de verdadeira fundamentação.

Palavras-chave: Gratuidade da justiça. Citação ficta. Curadoria especial. Defensoria Pública.

\begin{abstract}
The Brazilian Superior Court of Justice (STJ) has a majority opinion that the free legal aid should not be granted to the defaulting defendant under special curatorship, wich implies on the access-to-court obstruction. This work purposes the anlysis on STJ's decisions. Previously, two hypothesis are raised in order to explain the not granting of the benefit. The first would be the legal impossibility of granting the free legal aid petition presented by the special curatorhip, and the second would be the use of economic reasoning towards
\end{abstract}


the reduction of Judiciary expenses. From the decisions' analysis, however, the hypothesis are not verified, yet the absence of true judgement recital.

Keywords: Free legal aid. Constructive service of process. Special curatorship. Brazilian Public Defender's Office.

\section{SUMÁRIO}

INTRODUÇÃO 1. A CITAÇÃO FICTA E A CURADORIA ESPECIAL 2. A POSSIBILIDADE DA CONCESSÃO DA GRATUIDADE DE JUSTIÇA AO RÉU CITADO FICTAMENTE SOB CURADORIA ESPECIAL 3. OS CUSTOŚPÚBLICOS DO PROCESSO JUDICIAL BRASILEIRO 4. ANÁLISE DA JURISPRUDÊNCIA DO STJ SOBRE O CASO. CONSIDERAÇÓES FINAIS.

\section{INTRODUÇÃO}

"O Processo" ${ }^{\text {p }}$ pode ser real: ainda que pareça incomum, não raramente pessoas ausentes compóem o polo passivo de processos judiciais, podendo neles intervir no estado em que estiverem. ${ }^{2}$ Embora, para o leigo, a situação possa parecer inimaginável, o jurista sabe que isso é possível por meio do instituto da revelia, o qual, no Código de Processo Civil, abarca também as situaçóes de citação ficta, que são as citaçôes por edital e por hora marcada. Nesses casos, é nomeado um curador especial, papel assumido, geralmente, pelas Defensorias Públicas da União os dos Estados e Distrito Federal.

Perceba-se que nesse caso a curadoria especial difere da representação em juízo daquelas

\footnotetext{
1 Referência à obra homônima de Franz Kafka, um romance que narra a trágica história de um sujeito que, ao acordar, é surpreendido com a notícia de que responde a um processo, cujas razóes não compreende, agonia que trilha toda a narrativa.

2 Artigo 346, parágrafo único, da Lei no 13.105, de 2015: “O revel poderá intervir no processo em qualquer fase, recebendo-o no estado em que se encontrar".
} 
pessoas até certo tempo tidas como incapazes, ${ }^{3}$ ou de pessoas vulneráveis, por diversas razóes, pois trata-se de extrema fragilidade processual, ante a ausência do réu, independentemente do motivo, muitas vezes nunca sabido.

Portanto, o presente estudo surge da necessidade de se resolver um problema prático, que tem início porque as Defensorias frequentemente náo obtêm sucesso ao requererem os benefícios da justiça gratuita aos réus citados fictamente, ${ }^{4}$ questão agravada pela conhecida alta demanda das Defensorias, a despeito do orçamento limitado, sendo que sequer é devida a condenaçáo ao pagamento de honorários pelos entes que integram.

Entretanto, o Superior Tribunal de Justiça (STJ) vem decidindo que a insuficiência econômica do réu revel citado fictamente sob curadoria especial, mesmo a exercida pela Defensoria, não é presumida, entendimento há muito replicado em varas de variadas especialidades e tribunais no país.

Uma das consequências disso, no âmbito do STJ, é a decretação da deserção dos recursos pela ausência de pagamento do preparo, uma custa processual. $\mathrm{O}$ assunto recentemente foi tema de uma tímida, mas importante mudança de entendimento, no sentido de prestigiar o acesso à justiça. A temática principal que se coloca, porém, não diz somente respeito à dispensa do preparo recursal, e sim do custeio público da defesa do réu citado fictamente e representado, direta ou indiretamente, pelo aparelho estatal por meio da curadoria especial.

A fim de se analisar empiricamente a questão, inicialmente propóe-se uma breve explicaçáo sobre o instituto da curadoria especial no caso do réu citado fictamente, discutindo-se de que tipo de representação judicial se trata, e quais as funçóes e defesas que esse papel permite desempenhar.

A segunda parte do estudo discorre sobre duas hipóteses que poderiam justificar o posicionamento do STJ, levantadas ao longo do desenvolvimento: a impossibilidade jurídica do pedido ou, então, a ausência de fundamentação jurídica nas decisôes de não concessão

\footnotetext{
3 O espectro de incapacidade civil foi reduzido a partir das modificaçóes sobre o Código Civil promovidas pela Lei no 13.146, de 2015, a Lei Brasileira de Inclusão da Pessoa com Deficiência.

4 É curioso o fato apontado for Péricles Silva acera de recomendação da Coordenadoria Cível da Defensoria Pública do Estado do Rio de Janeiro, de março de 2018, para que os defensores redigissem a petição que requeria a gratuidade de justiça em nome da Curadoria Especial e não em nome da parte, a fim de facilitar o juízo de admissibilidade dos recursos (Disponível em: http://pec.defensoria.rj.def.br/exibir/noticia/5658Coordenadoria-civel-. Acesso em: 8 nov. 2019). SILVA, Péricles Batista da. Defensoria Pública e curadoria especial no Superior Tribunal de Justiça: a obrigatoriedade de recolhimento das custas de preparo como requisito de admissibilidade do recurso especial. Revista da Defensoria Pública do Distrito Federal, v. 1, n. 1, 2019, p. 123-136.

5 Tramita atualmente do STF o Recurso Extraordinário no 1140005, originário do Rio de Janeiro e sob relatoria do Min. Roberto Barroso, em que se discute a possibilidade de pagamento de honorários sucumbenciais às Defensorias Públicas pelos entes que integram, já tendo a Procuradoria Geral da União se manifestado em contrário à hipótese, na linha do que assentou o STJ pela Súmula no 421: "Os honorários advocatícios não são devidos à Defensoria Pública quando ela atua contra a pessoa jurídica de direito público à qual pertença”. Isso porque, em resumo, haveria confusão entre credor e devedor de honorários. De outro lado, quem defende o pagamento dos honorários encontra fundamento nas Emendas à Constituição de no 74/2013 e no 80/2014, sob o escopo de garantir a autonomia financeira, institucional e administrativa das Defensorias.
} 
no âmbito do STJ. Pretende-se verificar se pelo menos um desses fundamentos é presente nos julgados que exigem o preparo recursal.

A terceira parte da análise recairá sobre o custeio público do processo, em especial no caso da curadoria especial exercida pela Defensoria Pública. Por não terem sido localizados dados específicos, optou-se por expor resultados de pesquisas que tratam exclusivamente do custeio dos processos judiciais, a fim de se avaliar possíveis argumentos de racionalidade estritamente econômica.

Ao final, será realizada a verificação da jurisprudência do STJ, pela consulta ao seu banco de dados e análise qualitativa dos julgados, buscando-se o fundamento do posicionamento majoritário pela não concessão do benefício.

Como objetivo geral, assim, pretende-se discutir a situação da representação judicial do réu revel citado fictamente e seu direito de acesso à justiça e, a partir disso, promover uma reflexão sobre o sistema de acesso à justiça e custeio público do processo no Brasil e o papel do Judiciário nesse contexto.

\section{A CITAÇÁO FICTA E A CURADORIA ESPECIAL}

O réu citado fictamente, de fato, é um estranho no processo. Todavia, suprimir seu acesso à justiça por pressupor-se a má-fé seria parte de uma visão ultrapassada e incompatível com a atual formulaçáo do processo civil brasileiro. Como Calmon de Passos já defendia, ao afirmar que "o revel deixou de ser ausente para se tornar delinquente", ${ }^{6}$ Daniel Neves elucida que hoje "o réu revel não é um delinquente, mas um mero ausente, não devendo ser punido por nenhuma forma em razão de seu estado de revelia" .

Afinal, são muitas as razóes porque o réu é revel e, como conclui novamente Daniel Neves ${ }^{8}$ nenhuma delas importa. $\mathrm{Na}$ atual formatação do processo civil, a revelia não é punição imposta ao réu, de forma que nem sempre os seus efeitos se materializarão, como explica Lucio Delfino, ${ }^{9}$ em respeito ao paradigma do Estado Democrático de Direito, que deve propiciar um:

(...) ambiente no qual o contraditório funciona como garantia de in-

6 CALMON DE PASSOS, José Joaquim. Comentários ao Código de Processo Civil. v. III. 2. ed., 1977, p. 447 apud STRECK, Lenio Luiz; NUNES, Dierle; CUNHA, Leonardo Carneiro da (Orgs.); FREIRE, Alexandre (Coord. Exec.) Comentários ao Código de Processo Civil, 2017, p. 522.

7 NEVES, Daniel Amorim Assumpção. Manual de direito processual civil, 2019, p. 676.

8 NEVES, Daniel Amorim Assumpção. Manual de direito processual civil, 2019, p. 675.

9 DELFINO, Lucio. Capítulo VIII: Da revelia. In: STRECK, lenio Luiz; NUNES, Dierle; CUNHA, Leonardo Carneiro da (Orgs.); FREIRE, Alexandre (Coord. Exec.) Comentários ao Código de Processo Civil, 2017, p.523. 
fluência e não surpresa e onde as decisôes judiciais também se legitimam por intermédio de uma criteriologia que as mantenham atreladas à legalidade constitucionalizada e à historicidade jurisprudencial. ${ }^{10}$

Nessa linha, a revelia tem fundamento na razoável duração do processo e na eficiência, além do contraditório e da ampla defesa, daí que o art. 344 do Código de Processo Civil (CPC) garante que os efeitos da revelia não são aplicáveis a quaisquer casos, pelo que há quem defenda uma visão sistêmica, em que o juiz não é indiferente às particularidades do caso concreto. ${ }^{11}$

No que toca à análise legal, a citação, nos exatos termos do art. 238 do CPC, é o ato pelo qual são convocados o réu, o executado ou o interessado para integrar a relação processual. Para Pedro Henrique Nogueira, ${ }^{12}$ contudo, a redação é eivada de vício, porque não há uma convocação à relação processual, apenas dá-se a possibilidade de o réu ou o interessado apresentar sua defesa, porque, a partir da citação simplesmente já há a sua integração à demanda.

Na realidade, são antigas as discussões sobre a natureza jurídica da citação, e há em especial uma divergência sobre se se está diante de um requisito de validade ou de existência do processo. Essa questáo foi solucionada pelo art. 239 do CPC, que estabelece ser a citação um pressuposto de validade do processo, expressamente. ${ }^{13}$

10 Quer dizer, o Estado de Direito tem como pressuposto fundamental a legalidade, desde os seus primórdios. Depois, conforme a evolução desse modelo em cada experiência jurídica (formalmente constitucional, ou náo), existem outras características que se aderem, questão que pode ser bem analisada em TAMANAHA, Brian Z. On the rule of law: history, politics, theory. Cambridge University Press, New York, 2004 e PÉREZ LUÑO, Antonio Enrique. La universalidad de los derechos humanos y el Estado constitucional. Serie de teoria juridica y filosofia del derecho, n. 23. Universidad Externado de Colombia. Bogotá, 2002, que demonstram o gradual abandono de uma visão formalista do direito. DELFINO, Lucio. Capítulo VIII: Da revelia. In: STRECK, lenio Luiz; NUNES, Dierle; CUNHA, Leonardo Carneiro da (Orgs.); FREIRE, Alexandre (Coord. Exec.) Comentários ao Código de Processo Civil, 2017, p. 523.

11 DELFINO, Lucio. Capítulo VIII: Da revelia. In: STRECK, lenio Luiz; NUNES, Dierle; CUNHA, Leonardo Carneiro da (Orgs.); FREIRE, Alexandre (Coord. Exec.) Comentários ao Código de Processo Civil, 2017, p. 344.

12 NOGUEIRA, Pedro Henrique. Título II: da comunicação dos atos processuais. In: STRECK, lenio Luiz; NUNES, Dierle; CUNHA, Leonardo Carneiro da (Orgs.); FREIRE, Alexandre (Coord. Exec.) Comentários ao Código de Processo Civil, 2017, p. 363.

13 Esse já era o entendimento da doutrina majoritária, como nota Daniel Neves, que explica por que compreende por equívoco definir a citação como pressuposto de existência: "mesmo antes da citação do réu a relação jurídica processual já existe, ainda que formada exclusivamente entre autor e juiz", além de que há casos em que há julgamento de mérito antes da citaçáo, como dispóe o art. 332, tratando da hipótese de julgamento liminar improcedente mesmo antes da citação (NEVES, Daniel Amorim Assumpção. Manual de direito processual civil, 11 ed. Salvador: Ed. JusPodivm, 2019, p. 172-173). Da mesma forma, Nogueira (NOGUEIRA, Pedro Henrique. Título II: da comunicaçáo dos atos processuais. In: STRECK, Lenio Luiz; NUNES, Dierle; CUNHA, Leonardo Carneiro da (Orgs.); FREIRE, Alexandre (Coord. Exec.) Comentários ao Código de Processo Civil, 2017, p. 364) entende estar hoje ociosa a questáo, e concorda quanto ao ponto de que a ação existe a partir da propositura, ponto pacífico para Mitidiero, Marinoni e Arenhart, que notam que, na realidade, apenas os efeitos são produzidos contra o réu a partir da citação (MARINONI, Luiz Guilherme; ARENHART, Sérgio Cruz; MITIDIERO, Daniel. Novo curso de processo civil: tutela dos direitos mediante procedimento comum, vol. 2. Revista dos Tribunais, 2015, p. 129). 
De acordo com o Código de Processo Civil vigente (art. 246 e incisos), são admitidos cinco meios de citaçáo do réu, que são os correios, a diligência de oficial de justiça ${ }^{14}$, o comparecimento do réu em cartório, atendido pelo escrivão (técnico judiciário) ou chefe de secretaria, por edital ${ }^{15}$, ou o meio eletrônico, sendo este último uma novidade e de aplicação mais restrita. Da consulta aos arts. 252 a 256 do CPC, é possível notar que o legislador estabeleceu uma sequência de meios para a citação do réu, sendo a citaçáo por edital a última opção.

Neste ponto, é interessante que se saiba que tramita projeto de lei federal que visa a modificar os requisitos para que o réu seja considerado como estando em local ignorado ou incerto, hipótese que, afinal, enseja a citação por edital. Pela proposta, já emendada, as tentativas de localização seriam efetuadas no endereço informado pelo autor em cadastros públicos, à conta do Judiciário. ${ }^{16,17}$

No entanto, embora aparente ser uma boa solução à celeridade do processo, na realidade, pode apenas criar mais um problema, que é a presunção de ausência dada mais facilmente, a ser elidida exclusivamente por um réu que, até que tome conhecimento do fato, estará sob curadoria especial, geralmente, da Defensoria Pública, que já tem grandes demandas e orçamento limitado, restando ao réu, que eventualmente deixe de estar ausente, apenas tomar o processo no estado em que encontrar.

Existe certa controvérsia entre os autores sobre a natureza jurídica da curadoria especial exercida, em regra, pela Defensoria Pública no caso do réu citado fictamente, quando assim previr a lei, em especial a Lei Complementar no 80/1994, art. 4º, XVI.

14 Quanto à citação por hora certa, vale a consulta aos arts. 252 a 254 do CPC.

15 Nos termos do CPC:

"Art. 256. A citação por edital será feita:

I - quando desconhecido ou incerto o citando;

II - quando ignorado, incerto ou inacessível o lugar em que se encontrar o citando;

III - nos casos expressos em lei.

$\$ 1^{\circ}$ Considera-se inacessível, para efeito de citação por edital, o país que recusar o cumprimento de carta rogatória.

$\$ 2^{\circ}$ No caso de ser inacessível o lugar em que se encontrar o réu, a notícia de sua citação será divulgada também pelo rádio, se na comarca houver emissora de radiodifusão.

$\$ 3^{\circ} \mathrm{O}$ réu será considerado em local ignorado ou incerto se infrutíferas as tentativas de sua localizaçáo, inclusive mediante requisição pelo juízo de informaçôes sobre seu endereço nos cadastros de órgãos públicos ou de concessionárias de serviços públicos”.

16 Projeto de Lei no 21/2018. Inteiro teor do texto inicial da proposta e trâmite.

17 A diferença é que atualmente, pela redação do art. 256, parágrafo $3^{\circ}$, não se estabelece de que forma, e quantas vezes, se dará a tentativa de citaçáo por carta ou diligência de oficial de Justiça. O referido projeto busca, portanto, especificar as fontes públicas de informação sobre o réu, a fim de agilizar a citação através da criaçáo de uma presunçáo mais bem delimitada. Por exemplo, a respeito do pressuposto da citaçáo por edital, comum na execução fiscal, "É firme a jurisprudência deste Supremo Tribunal no sentido de ser válida a citação editalícia, feita com observância das normas legais respectivas, se a citaçáo pessoal não se torna possível, por não se encontrar o réu no endereço residencial indicado nos autos e não se faz prova idônea do contrário. Precedentes." (HC 96.540, Rel. Min. Cármen Lúcia, julgamento em 26-5-2009, Primeira Turma, DJE de 12-6-2009.) No mesmo sentido: HC 72.235, Rel. Min. Celso de Mello, julgamento em 28-3-1995, Primeira Turma, DJE de 4-12-2009 (STF, 2011, p. 313). 
O caso do réu revel citado fictamente demanda maior abstração que outras hipóteses de atuação da Defensoria Pública, pois se trata de representar interesses presumidos, diante de situação de extrema vulnerabilidade processual. Ressalte-se, de início, que a hipótese tratada neste estudo é a de citação ficta de pessoa certa e determinada, excluindo-se também a análise específica sobre as demandas coletivas. ${ }^{18}$

Para Fernanda Tartuce, ${ }^{19}$ não há de se falar em vulnerabilidade, que é verificada ao se analisar as condiçóes que circundam a vida da pessoa, e sim de fragilidade involuntária, a partir do que o legislador optou por oferecer certo grau de contraditório. Nessa linha, concordam Esteves e Silva ${ }^{20}$ que entendem se tratar de diminuição do impacto da citação ficta sobre o direito fundamental ao contraditório. Por seu turno, Carolina Bega ${ }^{21}$ conclui que existe, no caso do réu citado fictamente, a vulnerabilidade processual, sendo a curadoria especial tentativa de tutelar a igualdade processual.

No que concerne à classificação do CPC dos réus citados fictamente como revéis, Esteves e Silva ${ }^{22}$ lançam luz à matéria quando apontam uma atecnia sobre a redação do art. 72, II, segunda parte, do CPC. Isso porque, para eles, não seria caso de revelia, ${ }^{23}$ pois a intervenção de curador especial afasta a produção de efeitos substancial e procedimental da revelia.

De forma aproximada, Wambier e Talamini ${ }^{24}$ concluem que o efeito principal da revelia,

18 Como exemplo dado por Pericles Silva, o art. 554, parágrafo único, do CPC prescreve a atuação da Defensoria Pública em açôes possessórias nas quais figure no polo passivo um grande número de pessoas (SILVA, Pericles Batista da. Defensoria Pública e curadoria especial no Superior Tribunal de Justiça: a obrigatoriedade de recolhimento das custas de preparo como requisito de admissibilidade do recurso especial. Revista da Defensoria Pública do Distrito Federal, Brasília, v. 1, n. 1, 2019, p. 131). O dispositivo prevê a citação pessoal dos demandados que se encontrarem nos imóveis objetos das açôes, e a citação por edital dos demais, enquanto que à Defensoria Pública cabe a atuação quando se tratar de pessoas hipossuficientes economicamente. Porém, a redação não deixa claro se a Defensoria atuará quando aparentemente todos, inclusive os citados por edital, forem evidentemente hipossuficientes (é o caso de ocupaçóes irregulares de prédios urbanos, por exemplo), ou apenas daqueles citados pessoalmente. A respeito, contudo, concluem que a curadoria especial não se aplica aos citados fictamente, mas a Defensoria seria legitimada extraordinária a defender o polo passivo coletivo indeterminado (ESTEVES, Diogo; SILVA, Franklyn Roger Alves. A curadoria especial no novo código de processo civil. In: SOUSA, José Augusto Garcia. Repercussōes do novo CPC: Defensoria Pública, 2015).

19 TARTUCE, Fernanda. Igualdade e vulnerabilidade no processo civil, 2012, p. 420.

20 ESTEVES, Diogo; SILVA, Franklyn Roger Alves. Princípios institucionais da Defensoria Pública, 2018.

21 BEGA, Carolina Brambila. Curadoria especial - tutela da vulnerabilidade processual: análise da efetividade dessa atuação. Tese (Doutorado em Direito Processual) - USP, 2012, p. 40.

22 ESTEVES, Diogo; SILVA, Franklyn Roger Alves. A curadoria especial no novo código de processo civil. In: SOUSA, José Augusto Garcia. Repercussōes do novo CPC: Defensoria Pública, 2015, p. 553.

23 Quanto à revelia, é resumida por alguns autores como a falta de contestaçáo por parte do réu BUENO, Cassio Scarpinella. Curso sistematizado de direito processual civil: teoria geral do direito processual civil, vol. 1, 8. ed. São Paulo: Saraiva, 2014, p. 319). Em resumo, trata da ausência de resposta do réu, qual para Misael Montenegro Filho pode ser interpretada do ponto de vista objetivo (em respeito ao princípio da inatividade), que pode produzir efeitos em relação ao réu, que são: (a) presunçáo relativa de veracidade dos fatos afirmados pelo autor; (b) autorização para o julgamento antecipado da lide; (c) fluência de prazos independentemente de intimaçôes, pelo fato de o réu não ter demonstrado interesse pelo processo (MONTENEGRO FILHO, Misael. Novo código de processo civil comentado, 2016, p. 356).

24 WAMBIER, Luiz Rodrigues; TALAMINI, Eduardo. Curso avançado de processo civil: cognição jurisdicional (processo comum de conhecimento e tutela provisória), vol 2. Revista dos Tribunais, 2016. 
que é a presunção da veracidade dos fatos expostos na inicial (art. 344 do CPC), não é aplicável no caso do réu citado por edital. ${ }^{25}$

Enfim, para além dos efeitos distintos da revelia no caso dos réus citados fictamente, também a curadoria especial tem cunho protetivo, a fim de garantir a tutela dos direitos dessas pessoas. Essa função institucional atípica das Defensorias encontra previsão na Lei Complementar no 80/1994, art. 4º, XVI, e no CPC, art. 72, parágrafo único, cabendo ao Defensor Público, quando tem vistas no processo, determinar se o caso cuida de hipótese que demanda a atuação da Defensoria como curadora especial. ${ }^{26}$ Logo, não é o órgão judiciário quem define a pertinência da curadoria especial no caso concreto, mas não se olvide que, neste quesito, a hipótese do réu citado fictamente é mais simples.

Portanto, não haverá provimento judicial delimitando os poderes a serem exercidos pela Defensoria, tratando-se de matéria regulada em lei, embora não haja consenso a respeito do tipo de representação exercida nesse caso. A respeito, são apontadas três vertentes que fundamentariam a atuação da Defensoria Pública em geral: a teoria da representação processual, a teoria da substituição processual e a teoria distintiva. ${ }^{27}$

Segundo a linha que defende a espécie de representação processual, a Defensoria Pública atuaria em nome do curatelado e, portanto, defenderia um interesse alheio. Logo, não figuraria extraordinariamente como parte da relação jurídico-processual, como representante ad hoc nomeado pelo juiz, integrando a capacidade processual do representado. ${ }^{28}$ Contudo, nesse sentido, a Defensoria estaria representando incapazes, quando, na realidade, não é esse o papel que cumpre, porque a impossibilidade de representar certas pessoas em juízo, como as pessoas em privação de liberdade, é ocasional. ${ }^{29}$

A legitimidade extraordinária, entretanto, seria possível pela teoria da substituição processual, em que alguém postula em nome próprio a fim de defender interesse de outrem. A ressalva feita sobre essa linha é no sentido de que a substituição processual seria forma excepcional de legitimação, ocorrendo somente quando a parte estiver ausente. No caso da curadoria especial, diferentemente, o indivíduo continuaria presente na lide, apenas sem capacidade de estar em juízo sozinho. Logo, a funçáo da curadoria especial seria apenas complementar à legitimatio in processum..$^{30}$

Por fim, a teoria distintiva propóe que a curadoria especial seja analisada conforme cada

25 Existem casos em que a regra do art. 344 não se aplica, como nos processos autônomos de execuçáo, a partir de título executivo extrajudicial e, ademais, nas execuçóes fiscais, que sáo regidas subsidiariamente pelo Código de Processo Civil, conforme dita o art. $1^{\circ}$ da Lei 6.830/1980, a Lei de Execuçáo Fiscal.

26 ESTEVES, Diogo; SILVA, Franklyn Roger Alves. Princípios institucionais da Defensoria Pública, 2018, p. 540.

27 ESTEVES, Diogo; SILVA, Franklyn Roger Alves. Princípios institucionais da Defensoria Pública, 2018.

28 DIDIER JÚNIOR, Fredie. Curso de direito processual civil: introdução ao direito processual civil, parte geral e processo de conhecimento, 2017, p. 371.

29 DIDIER JÚNIOR, Fredie. Curso de direito processual civil: introdução ao direito processual civil, parte geral e processo de conhecimento, 2017, p. 371.

30 DIDIER JÚNIOR, Fredie. Curso de direito processual civil: introdução ao direito processual civil, parte geral e processo de conhecimento, 2017, p. 371. 
hipótese legal em que é prevista. Assim, a representação processual seria exercida em alguns casos apenas, especialmente, quando se tratar de pessoa incapaz. Entretanto, estando o réu ausente ou encarcerado, seria a vez da legitimação extraordinária. ${ }^{31}$

Em geral, contudo, boa parte dos autores entende pela teoria da substituição processual, elencando-se como fundamentos: a) o fato de o direito material náo estar à disposiçáo do substituto, a quem cabe a gestão processual; b) a possibilidade de a substituição apenas ocorrer após a formação processual (após citação, no caso de incapacidade superveniente, por exemplo); c) os efeitos da coisa julgada sobre o substituído; d) legitimidade extraordinária não decorrente de hipossuficiência econômica ou incapacidade jurídica, mas de outorga legal para evitar prejuízo jurídico, entre outros, como leciona Carolina Bega. ${ }^{32}$

Por ter a função de suprir a incapacidade processual da parte, o curador especial não está autorizado a renunciar direitos, não podendo, portanto, confessar, transacionar, reconhecer pedido da outra parte. Deve, por outro lado, defender o curatelado, postulando pela produção de provas, recorrendo e, inclusive, exercendo a defesa genérica, na forma do art. 341, parágrafo único, do CPC. ${ }^{33}$

Como comenta Theodoro Júnior, ${ }^{34}$ a curadoria especial permite uma faculdade ordinariamente negada ao réu, qual seja, a defesa por negação geral, de modo que cabe ao autor provar suas alegaçóes, mesmo quando não rebatidas especificamente. $\mathrm{O}$ benefício conferido pelo art. 341, parágrafo único, do $\mathrm{CPC}$, assim, garante a presunçáo de veracidade das alegaçóes da parte sob curadoria especial, o que, para Leonardo Greco, ${ }^{35}$ ainda náo retira sua posição de inferioridade, ou melhor, de vulnerabilidade no processo.

A razão das naturais limitaçóes aos instrumentos de defesa e, portanto, da desnecessidade de impugnação específica (visto por outro lado, do benefício da impugnação genérica), seria a falta de contato do curador especial com a parte, de forma que muitas vezes é impossível o conhecimento dos fatos. ${ }^{36}$ Essa questáo de ordem prática, embora pressuposta nesses casos, é o que aparentemente tem moldado a jurisprudência do STJ, conforme será visto adiante.

31 DIDIER JÚNIOR, Fredie. Curso de direito processual civil: introdução ao direito processual civil, parte geral e processo de conhecimento, 2017, p. 371.

32 BEGA, Carolina Brambila. Curadoria especial - tutela da vulnerabilidade processual: análise da efetividade dessa atuaçáo. Tese (Doutorado em Direito Processual) - USP, 2012.

33 Nessa linha, por exemplo, na fase de cumprimento ou no processo autônomo de execuçáo, pode o curador especial opor embargos em favor do réu revel citado fictamente, Súmula 196 do STJ), além de pleitear a declaração de extinção do feito por advento da prescrição intercorrente, no caso de execução fiscal, em especial (STJ, AgRg no REsp 783.024;MG. Rel. Min. Luiz Fux, Primeira Turma. 01.06.2006, DJe 19.06.2006) (BEGA, Carolina Brambila. Curadoria especial - tutela da vulnerabilidade processual: análise da efetividade dessa atuação Tese (Doutorado em Direito Processual) - USP, 2012, p. 124-127.

34 THEODORO JÚNIOR, Humberto. Curso de direito processual civil, vol. 1, 2019.

35 GRECO, Leonardo. Instituiçóes de processo civil [Recurso eletrônico], vol. 1, 2015.

36 SICA, Heitor Vitor Mendonça. Da contestação, p 840. In: Teresa Arruda Alvim Wambier, Fredie Didier Jr., Eduardo Talamini, Bruno Dantas, Breves comentários ao novo Código de Processo Civil, Revista dos Tribunais, 2015, p. 840 


\section{A POSSIBILIDADE DA CONCESSÁO DA GRATUIDADE DA JUSTIÇA AO RÉU CITADO FICTAMENTE SOB CURADORIA ESPECIAL}

O caso do réu revel citado por edital que pede os benefícios da gratuidade de justiça, embora aparentemente raro diante da diversidade de açóes em trâmite no Judiciário, no âmbito das Defensorias pode representar a concentraçâo de grandes demandas em poucas unidades ${ }^{37}$ considerando-se a vastidão do território brasileiro e a presença das Defensorias em parcela pequena das comarcas. ${ }^{38}$

Um dos questionamentos que surgem quando se analisa a situação do réu revel citado fictamente é a possibilidade de se conceder a este a justiça gratuita, e se quem exerce sua curadoria especial, afinal, gozaria de legitimidade para requerer nos autos esse benefício processual. A princípio, portanto, seria umas das hipóteses que justificariam a não concessão do benefício.

Essa indagação, embora pareça inócua, tem razão de existir. É que, quanto aos advogados, o art. 105 do CPC prevê que a procuração geral para o foro, outorgada por instrumento público ou particular, não permite que o patrono assine declaração de hipossuficiência econômica. Logo, como deve proceder o curador especial ao pedir à justiça gratuita aos seus representados réus revéis?

Para respondê-lo, é preciso lembrar que os benefícios da justiça gratuita, sem delongas, visam à facilitação do acesso à justiça, e encontram hoje guarida nos arts. 98 a 102 do CPC. O conjunto de requisitos principais para a concessão é ser a parte pessoa natural ou jurídica, brasileira ou estrangeira, com insuficiência de recursos para pagar as custas, as despesas processuais e os honorários advocatícios, conforme o caput do art. 98.

Além disso, conforme o art. 99, parágrafo $3^{\circ}$, é presumida a alegação de insuficiência (financeira) deduzida por pessoa natural, enquanto que a pessoa jurídica, portanto, deve comprovar a necessidade. Por fim, o caput do mesmo artigo prevê que o pedido pode ser formulado na inicial, na contestação e na petição para ingresso de terceiro ou, ainda, em

\footnotetext{
37 A título de exemplo, a Defensoria Pública do Estado da Bahia conta com oito unidades especializadas em curadoria especial. Informação disponível em: http://www.defensoria.ba.def.br/estrutura-organizacional/ coordenadoria-das-defensorias-publicas-especializadas/curadoria-especial/. Acesso em: 7 nov. 2019.

38 Em pesquisa divulgada em 2013, o Ipea concluiu que apenas $28 \%$ das comarcas eram atendidas pela Defensoria Pública (MOURA; CUSTÓRIO; SILVA; CASTRO. Mapa da Defensoria Pública no Brasil, 1 ed. Instituto de Pesquisa Econômica Aplicada, 2013, p. 19). A propósito, em 2014 foi publicada a Emenda Constitucional no 80, que operou a seguinte alteração sobre o Ato das Disposiçôes Constitucionais Transitórias (ADCT):

"Art. 98. O número de defensores públicos na unidade jurisdicional será proporcional à efetiva demanda pelo serviço da Defensoria Pública e à respectiva população.

$\$ 1^{\circ}$ No prazo de 8 (oito) anos, a União, os Estados e o Distrito Federal deverão contar com defensores públicos em todas as unidades jurisdicionais, observado o disposto no caput deste artigo.

$\$ 2^{\circ}$ Durante o decurso do prazo previsto no $\$ 1^{\circ}$ deste artigo, a lotação dos defensores públicos ocorrerá, prioritariamente, atendendo as regióes com maiores índices de exclusão social e adensamento populacional". Até o momento, contudo, não há dado oficiais publicados acerca da expansão territorial.
} 
recurso. Contudo, vem-se entendendo que, a qualquer momento, desde que sobrevenha a necessidade do benefício, pode ele ser requerido, embora não opere efeitos retroativos. ${ }^{39}$

Importa notar que a revogação de benefício da gratuidade pode, no futuro, acarretar prejuízos à parte, como alerta Rafael Oliveira, ${ }^{40}$ quando identificada a má-fé (art. 100, parágrafo único do CPC). Nessa linha, parece que a restrição imposta pelo CPC de 2015 é no sentido de resguardar parte e advogado, pois agora este não pode declarar a insuficiência de recursos daquele caso não tenha poderes especiais outorgados.

Finalmente, adentrando-se no questionamento deste tópico, o Defensor Público, de forma distinta do advogado privado, não atua sob outorga de mandato, estabelecendose relação público-estatutária, exercendo munus público, a partir do que tem atuação diferente daquela dos advogados privados. Por isso vale consultar o conteúdo da Lei Complementar no 80/1994:

Art. 128. São prerrogativas dos membros da Defensoria Pública do Estado, dentre outras que a lei local estabelecer:

\section{(...)}

XI - representar a parte, em feito administrativo ou judicial, independentemente de mandato, ressalvados os casos para os quais a lei exija poderes especiais.

$\mathrm{Na}$ literatura jurídica, enquanto alguns autores entendem ser imprescindível o mandato com outorga de poderes especiais para a prática de certos atos (art. 105 do CPC), outros compreendem que não necessariamente a anuência do assistido pela Defensoria Pública deverá ser expressa em instrumento de procuração, bastando simples autorização por escrito. ${ }^{41}$ De todo modo, essa discussão não é travada em vista da curadoria especial, mas da assistência jurídica comum.

Poder-se-ia concluir, então, que para assinar declaração de hipossuficiência de seu assistido, a Defensoria deveria apresentar instrumento de procuração com a outorga especial, ou pelo menos uma declaração do assistido com autorização específica, não sendo possível, nessa linha, a simples alegação em petição.

Diante disso, atente-se logo ao risco de se cair em uma espiral, pois é evidente que o réu revel não pode assinar qualquer procuração, por simplesmente ter paradeiro desconhecido. Logo, é tautológico afirmar que não se pode contatar o réu revel, pelo que é necessário que se entenda o contexto da tutela legal sobre esses casos.

39 NÚNEZ, Lucas Pahl Schaan. Uma análise racional do benefício da gratuidade judiciária e dos pressupostos para a sua concessão. Revista Eletrônica de Direito Processual, ano 12, vol 19, n.3, 2018 (set./ dez), p. 460-64).

40 OLIVEIRA, Rafael Alexandria de. Benefício da justiça, p. 320. In: Teresa Arruda Alvim Wambier, Fredie Didier Jr., Eduardo Talamini, Bruno Dantas, Breves comentários ao novo Código de Processo Civil, Revista dos Tribunais, 2015, p. 320.

41 ESTEVES, Diogo; SILVA, Franklyn Roger Alves. Princípios institucionais da Defensoria Pública, 2018, p. 347, p. 319-322. 
Como visto, não se permite a renúncia de direitos na curadoria especial..$^{42}$ De toda maneira, cabe perquirir se a exigência de mandato outorgando poderes especiais (art. 72 do CPC, tendo em vista o art. 128, XI da LC 80/1994) resguarda apenas os casos em que o assistido está presente - $\mathrm{e}$, assim, pode assinar procuração para que tenha certos interesses defendidos em juízo -, ou se a lei observa justamente as circunstâncias em que o indivíduo não está presente, ou seja, se a função pública exercida pela Defensoria Pública seria suficiente a pleitear o benefício.

Em análise das mudanças legislativas, o CPC de 1973 era silente quanto à possibilidade de o curador especial pedir os benefícios da justiça gratuita, apenas prevendo que os dispositivos alumiariam quanto à necessidade da outorga de poderes especiais (art. 38 do Código de Processo Civil revogado).

O acesso gratuito à justiça por sua vez, não era matéria do CPC de 1973, mas da Lei no 1.060, de 1950, qual conferia certas isençôes a partir da assistência judiciária gratuita, em seu art. $2^{\circ}$. O art. 16 dessa Lei, no parágrafo único, entretanto, também demandava a apresentação de mandato aos advogados integrantes de identidade de direito público e incumbido de prestação de assistência judiciária gratuita, quando seus atos demandassem poderes especiais. O CPC de 2015, por seu turno, é claro quando prevê a curatela especial ao réu citado fictamente, no art. 72 .

Também não se pode esquecer uma questáo importante, ressaltada em outro contexto por Esteves e Silva:

O contrato de mandato deve possuir caráter intuito personae, sendo a procuraçáo outorgada para pessoa certa e determinada. Essa característica legal, entretanto, apresenta absoluta incompatibilidade com o princípio institucional da indivisibilidade (art. $3^{\circ}$ da $\mathrm{LC} \mathrm{n}^{\circ}$ 80/1994), que permite a atuação sucessiva de diversos Defensores Públicos ao longo do processo. ${ }^{43}$

Transportando essa observação para o tema deste trabalho, conclui-se que a procuração com outorga de poderes especiais para o réu revel jamais deveria ser exigível, simplesmente por ser algo impossível.

Nessa linha, já foi matéria do informativo jurisprudencial do STJ o 560, o REsp. 1.431.043/MG, julgado em 2015, em que se assentou o entendimento de que, no processo penal, para a oposição da exceção de suspeição, seria necessária a procuração com poderes especiais, quando a Defensoria atuasse como representante da parte. Todavia, em se tratando de substituição, quando o réu estivesse ausente ou foragido, não seria exigível a procuração. ${ }^{44}$

42 Em outras palavras, o curador especial não pode dispor do direito material do réu, pelo que as hipóteses de imprescindibilidade da outorga de poderes especiais, como a confissão (art. 390, parágrafo $1^{\circ}, \mathrm{CPC}$ ), sequer lhe seriam aplicáveis.

43 ESTEVES, Diogo; SILVA, Franklyn Roger Alves. Princípios institucionais da Defensoria Pública, 2018 , p. 347.

44 STJ - REsp 1.431.043/MG, Rel. Min. Maria Thereza de Assis Moura, julgado em 16/4/2015, DJe 27/4/2015 (6a Turma). Informativo no 0560 (17 de abril a 3 de maio de 2015). 
Essa questão também foi analisada por Péricles Batista da Silva, ${ }^{45}$ que apontou, como solução possível frente à reiterada não concessão dos benefícios da gratuidade de justiça na situação em tela seria, o deferimento do pagamento das custas pelo vencido no final do processo, a teor do art. 91 do CPC de 2015, aplicável aos atos requeridos pela Defensoria Pública. De fato, poderia ser uma alternativa satisfatória na prática, mas o problema em si não é solucionado.

Há, ainda, outro viés a ser analisado. É que talvez o imbróglio da possibilidade de concessão, ou não, da gratuidade de justiça prevista no CPC seja um problema de importância menor frente à conclusão de que basicamente toda a atividade da Defensoria Pública está voltada à proteção de pessoas vulneráveis, o que demandaria a isenção de custas. ${ }^{46}$

A propósito, a Lei no 9.289/1996, que dispóe sobre as custas devidas à União no âmbito da Justiça Federal, não incluiu a Defensoria Pública como entidade isenta no rol do art. 40, ${ }^{47}$ resumindo a possibilidade de isenção para a Defensoria no inciso IV, caso autora de processo coletivo. ${ }^{48}$ De toda forma, é possível questionar se a Defensoria seria, ou não, isenta.

Note-se a semelhança da discussão com a polêmica do art. 1.015 do CPC, que trata das hipóteses de cabimento do agravo de instrumento, que para alguns é taxativo e, para outros, exemplificativo, ou de taxatividade mitigada, sendo esta a vertente mais inclinada a solucionar os problemas de incongruência entre os dispositivos do Código que surgiram pela redaçáo aparentemente taxativa do referido artigo. ${ }^{49}$

Os autores Fredie Didier Jr. e Leonardo Carneiro da Cunha, por exemplo, defendem a tese da taxatividade mitigada, entendendo que, para além da interpretação literal, devese analisar sistemática e criticamente o dispositivo em relação ao sistema, razão pela qual sustentam a necessidade da interpretaçáo extensiva sobre o artigo e, ademais, consequen-

45 SILVA, Péricles Batista da. Defensoria Pública e curadoria especial no Superior Tribunal de Justiça: a obrigatoriedade de recolhimento das custas de preparo como requisito de admissibilidade do recurso especial. Revista da Defensoria Pública do Distrito Federal, Brasília, v. 1, n. 1, 2019, p. 123/136.123.

46 Hoje defende-se, inclusive, a intervenção da Defensoria Pública como "custos vulnerabilis", uma forma de intervenção que teria por fundamento o art. $\$ 1^{\circ}$ do art. 554 do CPC e como objetivo a proteçáo de indivíduos e coletividades vulneráveis. A tese recentemente foi acolhida pelo STJ, na ocasião do julgamento dos EDcl no REsp. 1.712.163/SP (Segunda Seção do Superior Tribunal de Justiça, Relator Min. Moura Ribeiro, julgado em 25 set. 2019, DJe 27 set. 2019). Ainda mais recentemente foi publicada a obra "Custos Vulnerabilis: a Defensoria Pública e o equilíbrio nas relaçóes político-jurídicas dos vulneráveis”, de Edilson Santana, Jorge Bheron e Maurilio Casas Maia.

47 Art. $4^{\circ}$ São isentos de pagamento de custas:

(...) IV - os autores nas açôes populares, nas açóes civis públicas e nas açôes coletivas de que trata o Código de Defesa do Consumidor, ressalvada a hipótese de litigância de má-fé. (...).

Consulta à tramitação e inteiro teor do projeto disponíveis em: https://www.camara.leg.br/proposicoesWeb/ fichadetramitacao?idProposicao=582036. Acesso em 06 nov. 2019.

48 Art. $4^{\circ}$ São isentos de pagamento de custas:

(...) IV - os autores nas açóes populares, nas açóes civis públicas e nas açôes coletivas de que trata o Código de Defesa do Consumidor, ressalvada a hipótese de litigância de má-fé. (...).

49 REBELLO, Ana Beatriz F. Questão tratada em PRESGRAVE, O problema do rol taxativo do 1015: há uma soluçáo no CPC? Pensamos que sim!, 2017. 
cialista, a fim de evitar anomalias no sistema. ${ }^{50}$ Essa veio a ser, inclusive, a tese firmada pelo STJ quando do julgamento dos recursos repetitivos sob o tema de $n^{\circ} 988 .{ }^{51}$

Esse exemplo elucida, assim, a possibilidade de se estender a isençáo de custas nos processos da Justiça Federal para a Defensoria Pública, ou então para quem exerça a curadoria especial. Essa alternativa, contudo, demandaria uma atividade talvez excessivamente criativa do juiz, a partir da premissa de que, na realidade, não há completude no Direito, ${ }^{52}$ debate central nas discussóes sobre o papel do Judiciário no espaço democrático, afinal.

De outro lado, por todo o exposto acima, é evidente que existe uma dificuldade na legislação brasileira quanto ao exercício da função de curador especial, porque embora tenha o objetivo precípuo de permitir o acesso efetivo à justiça, não é clara a partir da interpretaçâo literal do texto legal a possibilidade da concessão da gratuidade ou, então, da aplicação da isenção de custas (na Justiça Federal), que afinal são prestaçôes positivas estatais que demandam motivação.

Sob outro viés, pela análise do sistema jurídico, é possível não se exigir o pagamento das custas ou do preparo recursal, por contrariar a lógica do sistema estabelecido a partir da Constituição de 1998 (art. 134) e do CPC de 2015, conforme se analisará.

\section{OS CUSTOS PÚBLICOS DO PROCESSO JUDICIAL BRASILEIRO}

Se o acesso à justiça é um direito de todos, é dever do Estado provê-lo. Mas como pode ser garantido, em qualidade, um sistema judiciário gigantesco em quilômetros quadrados e cifras, ${ }^{53}$ como é o brasileiro? Trata-se de uma questão das mais difíceis, a qual não se pretende responder neste trabalho.

A discussão é certamente ampla, de forma que será preciso reduzi-la para adaptar a matéria ao tema que se propóe. Em suma, para além do orçamento público destinado ao Judiciário (para pagamento de pessoal, manutenção predial, fornecimento de materiais, entre outras despesas), que tem origem na arrecadação de tributos, existem taxas cobradas do jurisdicionado para que este possa, efetivamente, ingressar em juízo. São exemplos dessas exigências o preparo recursal, os honorários pagos ao perito e as custas para uma série de manifestações processuais.

No caso do beneficiário da justiça gratuita, em circunstâncias regulares, será algum ente

50 DIDIER JÚNIOR, Freddie. Curso de direito processual civil: introdução ao direito processual civil, parte geral e processo de conhecimento, 2017, p. 209-211.

51 Disponível em: http://www.stj.jus.br/repetitivos/temas_repetitivos/pesquisa.jsp. Acesso em: 6 nov. 2019.

52 BOBBIO, Norberto. A era dos direitos, 2004, p. 122-127 (Trad. Carlos Nelson Coutinho).

53 Ao longo de 2018, os gastos efetivos do Judiciário, excluídas as despesas com gastos de inativos, somaram $\mathrm{R} \$ 76,8$ bilhóes, o que representa um gasto de $\mathrm{R} \$ 368,40$ por habitante, segundo relatório do Conselho Nacional de Justiça, que anualmente publica o "Justiça em Números”. CNJ. Conselho Nacional de Justiça. Justiça em Números. Brasília: CNJ, 2019. 
público o responsável por custear o seu processo. Ou seja, o erário público será onerado, embora por motivo justo, razoável e socialmente necessário, tema a ser suscitado mais adiante.

De toda maneira, como visto a respeito do art. $4^{\circ}$ da Lei no 9.289/96, náo há expressa previsão legal de isenção de custas para a Defensoria Pública, que é condicionada à gratuidade da justiça ou à assistência judiciária gratuita, em suma.

Ainda sobre o tema, atualmente tramita o Projeto de Lei ${ }^{\circ} 5.827 / 2013,{ }^{54}$ de autoria do STJ, que visa à atualização dos valores das custas na Justiça Federal. Entre as propostas está a isenção de pagamento de custas pela Defensoria Pública, sem a previsão de situaçóes específicas. A solução parece ser a mais adequada às atuais funçôes da Defensoria, abarcadas no art. 134 da Constituição Federal, que prevê a assistência desse órgão não só para os economicamente hipossuficientes, mas também para quaisquer necessitados, o que para Silva e Esteves ${ }^{55}$ permite a defesa de sujeitos ou grupos vulneráveis.

Por exemplo, a respeito do custeio da perícia pleiteada por beneficiário da justiça gratuita, resolvendo questáo antes apenas regulada pelo Conselho Nacional de Justiça, pela Resolução no 127/2011, o Código de Processo Civil de 2015 trouxe previsão explícita, devendo-se atentar aos parágrafos $3^{\circ}$ e $5^{\circ}$ do art. $95 .{ }^{56}$

Ou seja, no caso da perícia requerida pelo beneficiário da justiça gratuita, o custeio náo será suportado pela Defensoria Pública; e, sim, por recursos do Judiciário ou dos entes federativos. Assim, invariavelmente, a Defensoria Pública não irá custear a perícia, tarefa muitas vezes direcionada ao Judiciário. Eis, portanto, uma hipótese de argumento econômico como entrave à concessão desse benefício.

Os dados de um relatório do Conselho Nacional de Justiça mostram, contudo, que os gastos com a assistência judiciária gratuita equivalem a apenas 1,09\% do total das despesas do Poder Judiciário. ${ }^{57}$ Deve-se lembrar que a assistência judiciária gratuita e os benefícios da justiça gratuita são distintos, sendo a última um benefício de natureza processual e tri-

54 Consulta à tramitação e inteiro teor do projeto em: https://www.camara.leg.br/proposicoesWeb/ fichadetramitacao?idProposicao=582036. Acesso em: 6 nov. 2019.

55 ESTEVES, Diogo; SILVA, Franklyn Roger Alves. Princípios institucionais da Defensoria Pública, 2018, p. 389.

56 Art. 95. Cada parte adiantará a remuneração do assistente técnico que houver indicado, sendo a do perito adiantada pela parte que houver requerido a perícia ou rateada quando a perícia for determinada de ofício ou requerida por ambas as partes.

(...) $₫ 3^{\circ}$ Quando o pagamento da perícia for de responsabilidade de beneficiário de gratuidade da justiça, ela poderá ser:

I - custeada com recursos alocados no orçamento do ente público e realizada por servidor do Poder Judiciário ou por órgáo público conveniado;

II - paga com recursos alocados no orçamento da União, do Estado ou do Distrito Federal, no caso de ser realizada por particular, hipótese em que o valor será fixado conforme tabela do tribunal respectivo ou, em caso de sua omissão, do Conselho Nacional de Justiça.

(...) $₫ 5^{\circ}$ Para fins de aplicaçáo do $₫ 3^{\circ}$, é vedada a utilização de recursos do fundo de custeio da Defensoria Pública.

57 CNJ. Conselho Nacional de Justiça. Justiça em Números. Brasília: CNJ, 2019. 
butária, que garante a gratuidade de algumas despesas concretas, como a remuneração de tradutor ou intérprete, peritos e de advogado dativo, serviços ofertados por profissionais vinculados ao Judiciário. ${ }^{58}$

A assistência judiciária gratuita, por sua vez, tem um grande peso sobre as Defensorias Públicas, que são responsáveis, de fato, pelo atendimento daqueles que necessitam do auxílio estatal para a defesa de seus direitos, judicial ou extrajudicialmente, além de que, não havendo Defensoria na comarca, cabe a nomeação de um advogado dativo, a ser remunerado pelos cofres públicos (art. 22, $\$ 1^{\circ}$, da Lei no 8.906/1994). ${ }^{59}$ Além disso, o critério da hipossuficiência econômica não é o único adotado pelas Defensorias, ${ }^{60}$ de maneira que sua atuação é bastante abrangente.

No que diz respeito especificamente aos réus citados fictamente, o levantamento do $\mathrm{CNJ}^{61}$ não traz informaçôes. De toda maneira, é ônus do autor apresentar os dados do réu, e é difícil imaginar muitas situaçōes, de relaçôes jurídicas privadas, em que a parte passiva seja desconhecida, sendo mais comum que não se saiba o correto endereço do réu.

Contudo, em se tratando de relaçóes com entes públicos ou coletividades, torna-se mais provável a hipótese de desconhecimento do réu ou de sua localização. Um caso comum é a cobrança de anuidades por conselhos profissionais, ${ }^{62}$ perante os quais os inscritos têm o ônus de manter seus dados atualizados (perante o Fisco, em geral). Ocorre que, por desconhecimento ou outras razóes, não raramente essas pessoas deixam de atualizar seus cadastros, não efetuam o pagamento das anuidades e se tornam inadimplentes. Então, ocorre a inscrição dos créditos devidos aos conselhos em dívida ativa, a partir do que pode haver a execução fiscal.

O cenário não deve diferir muito em relação ao ano de 2011, quando o Instituto de Pesquisa Econômica Aplicada (Ipea) divulgou os resultados de um detalhado estudo (quantitativo e qualitativo) sobre o custo das execuçóes fiscais no âmbito da Justiça Federal. Vale citar o que se concluiu da análise dos dados:

Considerando-se as grandes rotinas que compōem o processo de execução fiscal, percebe-se que o cumprimento da etapa de citação constitui imenso gargalo inicial. Apenas 3,5\% dos executados apresentam-se voluntariamente ao juízo. Em $47,4 \%$ dos processos ocorre

\footnotetext{
58 ESTEVES, Diogo; SILVA, Franklyn Roger Alves. Princípios institucionais da Defensoria Pública, 2018, p. 347, p. 162)

59 O STJ, no julgamento de recursos repetitivos sob o tema $n^{\circ}$ 984, firmou a tese de que a remuneração dos advogados dativos náo é vinculada às tabelas de honorários elaboradas unilateralmente pelos Conselhos Seccionais da OAB, mas podem ser matéria de acordo entre as Seccionais, o Poder Público e as Defensorias Públicas.

60 ESTEVES, Diogo; SILVA, Franklyn Roger Alves. Princípios institucionais da Defensoria Pública, 2018, p. 347, p. 296.

61 CNJ. Conselho Nacional de Justiça. Justiça em Números. Brasília: CNJ, 2019.

62 Os conselhos profissionais são os maiores litigantes nas execuçôes fiscais depois da União, também segundo o $\mathrm{CNJ}$, em estudo sobre a atuação dos conselhos profissionais na cobrança de dívida ativa, publicado este ano: CNJ. Conselho Nacional de Justiça. Diagnóstico da atuaçáo dos conselhos profissionais na cobrança da dívida ativa. Brasília: CNJ, 2019.
} 
pelo menos uma tentativa inexitosa de citação, e em 36,9\% dos casos não há qualquer citação válida. Como a citação ocorre por edital em $6,4 \%$ dos casos, pode-se afirmar que em $43,5 \%$ dos executivos fiscais o devedor não é encontrado pelo sistema de justiça. ${ }^{63}$

Na prática, frustradas as tentativas usuais de citação do devedor, procede-se à publicação do edital de citação e, diante do não comparecimento ou constituição de advogado particular (revelia), é procedida a constituição da curadoria especial, que é uma função institucional da Defensoria Pública. Esta, por sua vez, frequentemente solicita o deferimento dos benefícios da justiça gratuita em nome do devedor, a fim de evitar despesas ao longo do processo. Nem sempre, porém, seu pleito é atendido.

A importância de se compreender a dinâmica do custeio das despesas processuais nesse caso particular lança luz a um debate mais amplo acerca do papel do Estado no custeio do acesso à Justiça, embora essa discussão não possa se alongar nas seguintes linhas.

De início, toda a discussão que se propóe tem como premissa o direito constitucional de acesso à justiça, exposto já no preâmbulo da Constituição de 1988, e no inciso LV do art. $5^{\circ}$, que assegura também a ampla defesa e o contraditório, além de se tratar de requisito para a formulação substantiva de um Estado de Democrático de Direito. ${ }^{64}$

Prosseguindo-se com a discussão, Gabriel Ignacio Marsan ${ }^{65}$ compreende que, embora a manutenção das defensorias públicas seja algo custoso ao Estado, e até mesmo contraditória, na perspectiva de que se exerce uma defesa contra o próprio Estado (representado pela acusação do Mistério Público ou pela coercibilidade do direito aplicado pelo juiz), cabe à Defensoria o papel subjetivo de defesa do acusado e papel objetivo de garantir o processo.

De mais a mais, complementa o autor, também é muito oneroso ao Estado cumprir direitos civis e políticos, bem como garantir liberdades individuais. Mas é necessário tornar esses direitos, inclusive o acesso à justiça, universais, o que está ligado à noção de isonomia, porque o direito à justiça deveria estar acessível a todos. ${ }^{66}$

A reflexão colocada, então, concerne ao custeio dos direitos, tema importante a partir do paradigma do Bem-Estar Social, em que, em linhas muito superficiais, o Estado assumiu a responsabilidade de prover certos direitos às pessoas, mas logo viu-se em dificuldades orçamentárias para tanto, surgindo, então, as discussóes sobre os limites da atuação estatal na garantia e promoção de direitos.

Nesse contexto, na teoria social-democrática dos direitos fundamentais, para Leonardo

\footnotetext{
63 IPEA. Instituto de Pesquisa Econômica Aplicada. Custo Unitário do Processo de Execuçáo Fiscal na Justiça Federal: Relatório de Pesquisa, 2011, p. 58).

64 TAMANAHA, Brian Z. On the rule of law: history, politics, theory. Cambridge University Press, 2004, p. 91.

65 MARSAN, Gabriel Ignacio Anitua. A defensoria pública como garantia de acesso à justiça. Revista da Defensoria Pública do Distrito Federal, v. 1, n. 1, 2019, p. 29.

66 MARSAN, Gabriel Ignacio Anitua. A defensoria pública como garantia de acesso à justiça. Revista da Defensoria Pública do Distrito Federal, v. 1, n. 1, 2019, p. 19-27.
} 
Martins, ${ }^{67}$ existe o problema da sujeição dos direitos à capacidade econômica do Estado, fazendo surgir figuras como a reserva do possível.

Assim, a decisão sobre o uso dos recursos financeiros acaba por ser transferida à discricionariedade legislativa e governamental, situação grave porque:

Essa mutação orgânico-institucional mediante intersecções por vezes ilegítimas nas típicas três funçóes estatais não vem devidamente acompanhada sequer de uma reengenharia juspublicístico-dogmática, quanto menos da necessária reflexáo teórica. ${ }^{68}$

Nota-se, portanto, que o argumento econômico dificilmente será o mais adequado no contexto da proteção de direitos fundamentais. Resta saber, afinal, se foi essa a linha seguida pelo STJ quando do julgamento de recursos interpostos para a defesa de réus fictamente citados sob a curadoria especial.

\section{ANÁLISE DA JURISPRUDÊNCIA DO STJ SOBRE O CASO}

Há quem defenda existir presunção de insuficiência econômica para fins da concessão da gratuidade da justiça quando há atuação da Defensoria Pública, mas que a exceção seria precisamente a situação do réu revel, por serem desconhecidas suas condiçôes. ${ }^{69}$

Esse parece ser o entendimento do STJ há anos, mas ultimamente algumas decisóes se puseram em outro sentido. Novamente, vale citar o estudo de Péricles Silva, que a partir da divergência jurisprudencial no âmbito do STJ concluiu que "não faz sentido a negativa de flexibilização da letra fria da lei em favor de uma exegese que privilegie o direito fundamental à ampla defesa”. A solução foi proposta, em suma, após análise legislativa a partir da qual o autor aduziu não haver previsão legal para a isenção do réu revel ao pagamento do preparo recursal. ${ }^{70}$

A fim de investigar o histórico jurisprudencial do Superior Tribunal de forma acurada, propóe-se neste estudo a consulta ao banco de dados do referido tribunal, com a adoção de certos parâmetros que permitam uma amostragem satisfatória de julgados, para entáo se iniciar a análise qualitativa.

Conforme já se alertou na Introdução, a decisão pela seleção de julgados do STJ é motivada pelo fato de ser este o tribunal responsável pela uniformizaçáo da jurisprudência no Brasil, pelo menos desde a vigência do CPC de 2015. Assim, é de se esperar que o entendimento

67 MARTINS, Leonardo; DIMOULIS, Dimitri. Teoria geral dos direitos fundamentais, 2014.

68 MARTINS, Leonardo; DIMOULIS, Dimitri. Teoria geral dos direitos fundamentais, 2014, p. 11.

69 ROCHA, Amélia Soares. Defensoria Pública: fundamentos, organização e funcionamento, 2013.

70 SILVA, Péricles Batista da. Defensoria Pública e curadoria especial no Superior Tribunal de Justiça: a obrigatoriedade de recolhimento das custas de preparo como requisito de admissibilidade do recurso especial. Revista da Defensoria Pública do Distrito Federal, v. 1, n. 1, 2019, p. 131. 
do STJ seja replicado nos Tribunais de Justiça e Varas de Justiça Comum, pelo menos.

Perceba-se, ainda, que os julgados selecionados trarão a discussão sobre a concessão, ou não, da gratuidade, ou entáo da dispensa de apresentação do preparo recursal. Isso não quer dizer que não existam julgados em que o preparo é dispensado. É que o sistema disponibilizado online pelo STJ, assim como ocorre em outras cortes, permite somente a busca de palavras-chave na ementa, o resumo do julgado.

Assim, naturalmente, os julgados que resultam da busca a ser descrita a seguir tratam especificamente de casos em que se discute a dispensa do preparo, geralmente em sede de agravo interno, motivado muitas vezes exclusivamente por essa questáo.

Em suma, procedeu-se pela inserção de parâmetros de busca distintos, com conjuntos de palavras: a) "defensoria réu revel gratuita"; b) "curador especial revel gratuita"; c) "revelia gratuita curador"; d) "defensoria curadora especial justiça gratuita".

Antes, foram testados outros conjuntos, entretanto obteve-se um maior número e julgados dessa forma, sem uso de conectivos, após perceber-se que refinariam ainda mais a busca sem, no entanto, realmente selecionar os julgados pertinentes. O lapso temporal da busca não foi delimitado, mas deve-se considerar que as buscas foram feitas até dezembro de $2019,{ }^{71}$ o que significa que os resultados iniciam em um tempo indeterminado, inclusive anterior à vigência do CPC de 2015, até o final de dezembro de 2019. No total, descartados julgados não pertinentes com o assunto, ou os repetidos, teve-se um universo de 28 acórdãos analisados, que permitiram todos a formação de coisa julgada material. ${ }^{72}$

A fim de simplificar o resultado da seleção dos julgados para a análise qualitativa, propóese o quadro abaixo:

\footnotetext{
$71 \quad$ Inicialmente, as pesquisas abrangeram julgados até o ano de 2018. Após a aprovação do artigo para publicação, foram replicados os mesmos parâmetros no buscador disponível no banco de julgados do STF, contudo empreendendo todo o ano de 2019, a fim de atualizar o estudo. Dos quatro julgados resultantes, apenas um apresentou pertinência temática. O primeiro tratava da aplicação do CPC de 1973 em caso que não envolvia curadoria especial (AgInt no AResp 1337216/RJ), o segundo tratou de curadoria especial exercida pela Defensoria Pública da União em prol de "pessoa incapaz" (AgInt no Resp 1751047/RJ), embora na fundamentação haja citação de julgados versando sobre o caso do réu citado fictamente; no terceiro (AgInt $1346190 / \mathrm{RJ})$, o Resp fora interposto pelo autor, ou seja, não se tratou de réu revel pleiteando a gratuidade de justiça nem a dispensa da apresentaçáo do preparo, embora também tenha sido citado trecho de julgado que considerou deserto o recurso apresentado pelo réu revel sob curadoria especial da Defensoria Pública. Por fim, quarto julgado foi o Acórdão sobre EDv em AResp no 1.052.418 - RJ, que reformou o AgInt no AREsp 1052418/RJ (03/08/2017), no sentido de dispensar a apresentação do preparo recursal e, entấo, afastar a deserção.

72 Após a aprovação do artigo para publicação, em março de 2020, foi consultado o trâmite processual de todos os julgados selecionados. Boa parte transitou em julgado. Os julgados reformados no tocante à exigência ou não do preparo foram apenas o Acórdáo sobre o AgInt no AREsp 1052418/RJ, a partir de EDv nos EAREsp (28/02/2020) e o Acórdáo sobre o AgRg no REsp 1542650/TO, a partir de EDv em Resp (26/11/2019). No quadro constam esses dados já atualizados.
} 
QUADRO I - RESUMO DA SELEÇÃO DOS JULGADOS DO STJ

\begin{tabular}{|c|c|c|c|c|}
\hline $\begin{array}{l}\text { Número do } \\
\text { julgado }\end{array}$ & Curador(a) especial & Órgão prolator & $\begin{array}{l}\text { Data do } \\
\text { Acórdão }\end{array}$ & Síntese \\
\hline $\begin{array}{l}\text { AgInt no AREsp } \\
1108665 / \mathrm{ES}\end{array}$ & Defensoria Pública da Uniāo & Primeira Turma & $28 / 08 / 2018$ & 3 \\
\hline $\begin{array}{l}\text { AREsp } 978895 \\
(2016 / 0235671-0 \\
\text { de } 04 / 02 / 2019) \\
\end{array}$ & Defensoria Pública da Uniāo & Corte Especial & $04 / 02 / 2019$ & 3 \\
\hline $\begin{array}{l}\text { AgInt no REsp } \\
1674495 / \mathrm{SP}\end{array}$ & $\begin{array}{l}\text { Defensoria Pública do } \\
\text { Estado de São Paulo }\end{array}$ & Terceira Turma & $26 / 04 / 2018$ & 1 \\
\hline $\begin{array}{l}\text { AgInt no AREsp } \\
1045263 / \mathrm{RJ}\end{array}$ & $\begin{array}{l}\text { Defensoria Pública do } \\
\text { Estado do Rio de Janeiro }\end{array}$ & Segunda Turma & $22 / 02 / 2018$ & 2 \\
\hline $\begin{array}{l}\text { AgInt no RCD no } \\
\text { REsp 1645186/ } \\
\text { MG }\end{array}$ & Defensoria Pública da Uniāo & Quarta Turma & $05 / 09 / 2017$ & 1 \\
\hline $\begin{array}{l}\text { AgRg no REsp } \\
1555758 / \mathrm{PR}\end{array}$ & Advogado(a) dativo(a) & Quarta Turma & 03/08/2017 & 4 \\
\hline $\begin{array}{l}\text { AgInt no AREsp } \\
\text { 986631/RJ }\end{array}$ & $\begin{array}{l}\text { Defensoria Pública do } \\
\text { Estado do Rio de Janeiro }\end{array}$ & Terceira Turma & $15 / 12 / 2016$ & 1 \\
\hline $\begin{array}{l}\text { EDv em REsp } \\
1542650 / \mathrm{TO}\end{array}$ & $\begin{array}{l}\text { Defensoria Pública do } \\
\text { Estado do Tocantins }\end{array}$ & $\begin{array}{l}\text { Decisão } \\
\text { Monocrática que } \\
\text { reformou Acórdão } \\
\text { proferido pela } \\
\text { Segunta Turma }\end{array}$ & $26 / 11 / 2019$ & 3 \\
\hline $\begin{array}{l}\text { AgRg no AREsp } \\
630701 / \mathrm{MG}\end{array}$ & $\begin{array}{l}\text { Defensoria Pública do } \\
\text { Estado de Minas Gerias }\end{array}$ & Terceira Turma & $16 / 06 / 2015$ & 2 \\
\hline $\begin{array}{l}\text { AgRg no AREsp } \\
10183 / \mathrm{MG}\end{array}$ & Defensoria Pública da Uniāo & Quarta Turma & $24 / 03 / 2015$ & 1 \\
\hline $\begin{array}{l}\text { EDcl no AREsp } \\
49499 / \mathrm{ES}\end{array}$ & Advogado(a) dativo(a) & Terceira Turma & $01 / 04 / 2013$ & 4 \\
\hline $\begin{array}{l}\text { AgRg no REsp } \\
1345670 / \mathrm{PR}\end{array}$ & Advogado(a) dativo(a) & Segunda Turma & $18 / 12 / 2012$ & 4 \\
\hline $\begin{array}{l}\text { AgRg no REsp } \\
817621 / \text { ES }\end{array}$ & Advogado(a) dativo(a) & Terceira Turma & $31 / 08 / 2011$ & 4 \\
\hline $\begin{array}{l}\text { AgRg no REsp } \\
1186284 / \mathrm{MS}\end{array}$ & Defensoria Pública da Uniāo & Terceira Turma & $03 / 12 / 2010$ & 1 \\
\hline $\begin{array}{l}\text { AgRg no AREsp } \\
737263 / \mathrm{MS}\end{array}$ & Defensoria Pública da Uniāo & Quarta Turma & $15 / 10 / 2015$ & 1 \\
\hline
\end{tabular}




\begin{tabular}{|c|c|c|c|c|}
\hline $\begin{array}{l}\text { AgRg no Ag } \\
1148322 / \mathrm{RJ}\end{array}$ & $\begin{array}{l}\text { Defensoria Pública do } \\
\text { Estado do Rio de Janeiro }\end{array}$ & Quarta Turma & $15 / 10 / 2009$ & 1 \\
\hline $\begin{array}{l}\text { AgInt no AREsp } \\
1161521 / \text { AM }\end{array}$ & $\begin{array}{l}\text { Defensoria Pública do } \\
\text { Estado do Amazonas }\end{array}$ & Segunda Turma & $15 / 05 / 2018$ & 1 \\
\hline $\begin{array}{l}\text { AgInt no REsp } \\
1674495 / \text { SP }\end{array}$ & $\begin{array}{l}\text { Defensoria Pública do } \\
\text { Estado de Sáo Paulo }\end{array}$ & Terceira Turma & $26 / 04 / 2018$ & 1 \\
\hline $\begin{array}{l}\text { AgInt no AREsp } \\
\text { 982334/MG }\end{array}$ & Defensoria Pública da União & Segunda Turma & $11 / 05 / 2017$ & 1 \\
\hline $\begin{array}{l}\text { AgRg no AREsp } \\
288811 / \mathrm{MG}\end{array}$ & $\begin{array}{l}\text { Defensoria Pública do } \\
\text { Estado de Minas Gerais }\end{array}$ & Quarta Turma & $14 / 03 / 2017$ & 1 \\
\hline $\begin{array}{l}\text { AgInt no REsp } \\
1607617 / \text { AC }\end{array}$ & Defensoria Pública da União & Primeira Turma & 03/02/2017 & 1 \\
\hline $\begin{array}{l}\text { AgInt no REsp } \\
1614110 / \mathrm{SP}\end{array}$ & Defensoria Pública da União & Quarta Turma & $14 / 12 / 2016$ & 1 \\
\hline $\begin{array}{l}\text { AgRg no AREsp } \\
718539 / \mathrm{RJ}\end{array}$ & $\begin{array}{l}\text { Defensoria Pública do } \\
\text { Estado do Rio de Janeiro }\end{array}$ & Primeira Turma & $15 / 08 / 2016$ & 1 \\
\hline $\begin{array}{l}\text { EDcl no AgRg no } \\
\text { AREsp 738813/RS }\end{array}$ & $\begin{array}{l}\text { Defensoria Pública do Estado } \\
\text { do Rio Grande do Sul }\end{array}$ & Quarta Turma & $18 / 08 / 2017$ & 3 \\
\hline $\begin{array}{l}\text { AgRg no AREsp } \\
\text { 556355/MG }\end{array}$ & $\begin{array}{l}\text { Defensoria Pública do } \\
\text { Estado de Minas Gerais }\end{array}$ & Primeira Turma & $20 / 02 / 2015$ & 1 \\
\hline $\begin{array}{l}\text { AgRg no REsp } \\
\text { 846478/MS }\end{array}$ & Defensoria Pública da Uniāo & Quarta Turma & $26 / 02 / 2007$ & 1 \\
\hline $\begin{array}{l}\text { EDv nos EAREsp } \\
1052418 / \mathrm{RJ}\end{array}$ & Defensoria Pública da União & $\begin{array}{l}\text { Decisão } \\
\text { Monocrática } \\
\text { que reformou } \\
\text { Acórdão } \\
\text { proferido pela } \\
\text { Segunda Turma }\end{array}$ & $28 / 02 / 2020$ & 3 \\
\hline $\begin{array}{l}\text { AgInt no AREsp } \\
\text { 1233877/ES }\end{array}$ & $\begin{array}{l}\text { Defensoria Pública do } \\
\text { Estado do Espírito Santo }\end{array}$ & Primeira Turma & $13 / 09 / 2018$ & 3 \\
\hline
\end{tabular}

Legenda: Classificadores das decisōes: 1) Negado seguimento ao Resp interposto por pessoa física por ausência do preparo, vez que não se presume a gratuidade de justiça quando da representaçáo exercida pela Defensoria Pública; 2) Negado seguimento ao Resp interposto por pessoa jurídica por ausência do preparo, vez que não se presume a gratuidade de justiça quando da representação exercida pela Defensoria Pública; 3) Recurso provido ou acolhido. Dispensa da apresentaçáo do preparo recursal. Gratuidade de justiça não analisada; 4) Negado seguimento ao Resp. interposto por pessoa física representada por advogado(a) dativo(a) nomeado(a) pelo Juízo, por náo ser o(a) curador(a) especial integrante da Defensoria Pública, e vez que não se presume a gratuidade de justiça quando do exercício da curadoria especial. 
Como resultado, em resumo, percebe-se que parcela significativa dos julgados foi no sentido de entender que não se presume a insuficiência de recursos da parte que é citada fictamente e assistida pela Defensoria Pública, enquanto curadora especial, porque não há contato entre o réu ausente e o Defensor, que não pode verificar a situação do assistido. ${ }^{73}$

Ressalta-se que em nenhum dos casos se levantou a ilegitimidade da Defensoria para pleitear a justiça gratuita em favor de réu citado fictamente, fundamentando-se apenas na impossibilidade de o curador especial conhecer a situaçáo financeira de ausente.

Entretanto, nos casos em que a parte revel foi representada por advogado dativo, no exercício da curadoria especial, o primeiro fundamento lançado nos julgados era quanto ao fato de a parte não estar sendo representada pela Defensoria Pública, o que não presumiria a gratuidade de justiça e, enfim, o fato de não se presumir a gratuidade no caso do réu revel.

Evidente, assim, a ausência de uniformidade entre os julgados do STJ, que ainda antes do novo entendimento ora exigiam a apresentação do preparo recursal quando o réu estava sob curadoria especial de advogado dativo, ao argumento de que o benefício somente seria concedido no caso da representação exercida pela Defensoria Pública, ora também exigiam o preparo da Defensoria Pública enquanto curadora especial, que foi a situação encontrada na maior parte dos julgados analisados. Percebe-se, de pronto, o labirinto da temática.

Ainda, quase todos os julgados trataram de Agravos Internos sobre Recursos Especiais. É que, em razão da não presunção da gratuidade de justiça, como no AgInt no AREsp no 1045263/RJ e no AgInt no REsp 1674495/SP, quando da análise dos recursos especiais, decidiu-se pela necessidade do preparo, resultando no não provimento, seguida da interposiçáo de agravos internos, também desprovidos. Ou seja, o pedido nos agravos internos geralmente é exclusivamente a dispensa do preparo recursal.

Embora o entendimento reiterado do STJ seja no sentido de negar a justiça gratuita ao réu revel sob curadoria especial da Defensoria Pública, com as ressalvas já feitas, houve alguns julgados, como o AgInt no AREsp 1108665/ES74 e o AgInt no AREsp 1233877/ $\mathrm{ES}^{75}$, que sinalizaram para uma possível virada jurisprudencial.

O primeiro foi relatado pelo Ministro Gurgel de Faria, que foi o relator para acórdão do segundo, que por sua vez fora relatado pelo Ministro Sérgio Kukina, cujo voto foi vencido. Nesses dois casos, foi dispensado o preparo para a interposição do Recurso Especial, no caso da curadoria especial.

73 Com uma considerável quantidade de precedentes citados: STJ, AgInt no RCD no REsp 1.645.186/ MG, Rel. Ministro ANTONIO CARLOS FERREIRA, QUARTA TURMA, DJe de 05/09/2017; STJ, AgInt no AREsp 913.137/BA, Rel. Ministro MAURO CAMPBELL MARQUES, SEGUNDA TURMA, DJe de 14/11/2016 e AgInt no AREsp 942.537/BA, Rel. Ministro OG FERNANDES, SEGUNDA TURMA, DJe de 24/10/2016.

74 Inteiro teor do acórdão disponível em: https://ww2.stj.jus.br/websecstj/cgi/revista/REJ.cgi/ITA?se$\mathrm{q}=1739157 \&$ tipo $=0 \&$ nreg $=201701236488 \&$ SeqCgrmaSessao $=\&$ CodOrgaoJgdr $=\& d t=20180918 \&$ forma to $=$ PDF\&salvar=false. Acesso em: 22 de fev. 2019.

75 Inteiro teor do acórdāo disponível em: https://ww2.stj.jus.br/processo/revista/documento/mediado/? componente=ITA\&sequencial $=1739162 \&$ num_registro $=201800111512 \&$ data $=20180913 \&$ formato $=P D F$. Acesso em: 22 de fev. 2019. 
Nos votos, que inclusive citam os precedentes já comentados acima (AgRg no REsp 1345670/PR e EDcl no AREsp 49499/ES), fundamenta-se no exercício do munus público exercido pela Defensoria, que deveria ser estendido ao grau recursal. Nessa esteira, a negativa da prestação jurisdicional (pelo não provimento dos recursos em razão da não pagamento do preparo), para o referido Ministro, impediria a garantia constitucional da ampla defesa a que se presta a Defensoria Pública enquanto curadora especial.

Vale ressaltar que uma solução possível, como a concessão da gratuidade de justiça para atos específicos (art. 98, parágrafo 50), na casuística aqui analisada, sequer foi cogitada nos julgados, ante o entendimento hermético de que o curador especial não pode verificar as condiçóes financeiras do réu ausente, ou talvez por ausência do pedido específico pela concessão da gratuidade de justiça em sede recursal (o que é permitido pelo art. 99, parágrafo $7^{\circ}$, do CPC). Também a alternativa lançada por Péricles Silva, ${ }^{76}$ o diferimento das custas ao final do processo, não foi questáo suscitada.

Portanto, não se enfrentou diretamente a questão da concessão da justiça gratuita, ressaltando-se que ela não é presumida quando se tratar de réu citado fictamente e fundamentando-se na necessidade de acesso à justiça, que resta inviabilizado quando se exige o preparo recursal da Defensoria Pública. O fundamento das decisóes que permitiu a dispensa dos preparos teve por base não a legislação de processo civil, e sim a necessidade de se concretizar o princípio do acesso à justiça, além da observância das funçôes precípuas da Defensoria Pública.

Ainda assim, não se delineou qualquer discussão acerca da possibilidade de isenção de custas para a Defensoria Pública, na linha de uma interpretaçáo extensiva da Lei no 9.289/1996, tampouco se utilizou de marcas denotativas de argumentos de cunho econômico, porque a fundamentaçáo dos julgados, verificáveis em especial nos votos dos Relatores, foi reiteradamente resumida a se informar a orientação prevalecente no STJ, embora, como visto, o posicionamento do STJ tenha sido vacilante.

\section{CONSIDERAÇÓES FINAIS}

Mauro Capelletti e Bryant Garth ${ }^{77}$ revisaram várias experiências ao redor do globo que objetivavam facilitar o acesso à justiça, em seus diversos aspectos. Analiticamente, perceberam algumas "ondas" ou fases do desenvolvimento do sistema jurídico de muitos países, desde a construção de um aparato estatal apto a atender os mais necessitados, com a destinação de recursos para tanto, de mecanismos processuais de tutela de direitos coletivos, até novas formas de resolução de conflitos, como a arbitragem.

76 SILVA, Pericles Batista da. Defensoria Pública e curadoria especial no Superior Tribunal de Justiça: a obrigatoriedade de recolhimento das custas de preparo como requisito de admissibilidade do recurso especial. Revista da Defensoria Pública do Distrito Federal, Brasília, v. 1, n. 1, 2019, p. 131.

77 CAPPELETTI, Mauro; BRYANT, Garth. Acesso à justiça, 1988, p. 160 (Trad. Hellen Gracie Northfleet). 
Os autores alertam, porém, que se deve evitar a ilusão de achar que reformas sobre leis e sistemas processuais implicam necessariamente mudanças políticas e sociais. ${ }^{78}$ Logo, o caminho mais certo parece ser justamente o oposto, afinal, em tese a lei é a expressão da vontade popular.

Como elucidou Norberto Bobbio, no clássico "A Era dos Direitos", ${ }^{79}$ o surgimento de novas demandas por direitos não significa a superação de velhos problemas. Ao passo que são reconhecidas muitas pretensóes novas, não deixa de existir a inefetividade de direitos básicos. Essa talvez seja uma boa descrição para o complexo cenário brasileiro.

Tendo esses desafios em vista, feita a análise dos julgados, foi revelado o perfil jurisprudencial do STJ, até pouco tempo tendente a não se dispensar a apresentação do preparo recursal pelo réu fictamente citado e sob curadoria especial. Principalmente, deixou claro o simplismo na fundamentação das decisões, que não enfrentaram a devida análise legal, mormente as alteraçóes promovidas pelo CPC de 2015 e, em suma, reiteravam os precedentes no sentido de que "o deferimento dos benefícios da justiça gratuita não se presume, mesmo nos casos em que a Defensoria Pública atue como curador especial de réu revel", por não ser possível a verificaçáo de hipossuficiência do réu.

Por conseguinte, as duas hipóteses levantadas no início deste estudo (a impossibilidade jurídica do pedido pela ilegitimidade do curador especial, ou a aplicação de argumento econômico na decisão) não se aplicaram aos casos, ou pelo menos não fizeram parte da fundamentação das decisões.

A análise proposta concluiu, assim, primeiramente, que uma atecnia da lei, ou a sua interpretação estritamente silogística, tem causado a negativa de defesa de um número indeterminado de pessoas em varas e tribunais brasileiros.

Em segundo lugar, e talvez mais importante, foi possível depreender que as decisóes judiciais não foram suficientemente fundamentadas, e sim reduzidas a um argumento redundante, o que pode sinalizar a deficiência na integridade e na coerência da interpretação da lei. ${ }^{80}$ Talvez seja sinal de que a Têmis deve permanecer de olhos fechados, mas atenta às soluções muito simples.

78 CAPPELETTI, Mauro; BRYANT, Garth. Acesso à justiça, 1988, p. 160 (Trad. Hellen Gracie Northfleet).

79 BOBBIO, Norberto. A era dos direitos, 2004. (Trad. Carlos Nelson Coutinho).

$80 \mathrm{O}$ art. 489 do CPC impôe o dever de fundamentaçâo da decisão judicial; ainda que baseada em precedentes, conforme o inciso $\mathrm{V}$ do parágrafo $1^{\circ}$, o juiz deve identificar seus fundamentos determinantes e demonstrar que o caso sob julgamento se ajusta àqueles fundamentos. Para Túlio Jales (2015), cuida-se da superação do paradigma positivista de fundamentação, pois apenas a menção à fonte normativa, incluindo os precedentes, não resulta em uma decisão moralmente justificada. 


\section{REFERÊNCIAS}

BEGA, Carolina Brambila. Curadoria especial - tutela da vulnerabilidade processual: análise da efetividade dessa atuação. Tese (Doutorado em Direito Processual) - USP, São Paulo, 2012.

BOBBIO, Norberto. A era dos direitos. Rio de Janeiro: Elsevier, 2004. (Trad. Carlos Nelson Coutinho).

. Teoria do ordenamento jurídico, 6 ed. Brasília: Editora Universidade de Brasília. 1995. (Trad. Maria Celeste C.J. Santos).

BRASIL. Senado Federal. Projeto de Lei no 21/2018. Altera o art. 256 da Lei no 13.105, de 16 de março de 2015 (Código de Processo Civil), para dispor sobre a citação, por edital, do réu com endereço desconhecido. Disponível em: https://www25.senado.leg.br/ web/atividade/materias/-/materia/132142?o=c. Acesso em: 29 set. 2019.

BUENO, Cassio Scarpinella. Curso sistematizado de direito processual civil: teoria geral do direito processual civil, vol. 1, 8. ed. São Paulo: Saraiva, 2014.

CALMON DE PASSOS, José Joaquim. Comentários ao Código de Processo Civil. v. III. 2. ed., Rio de Janeiro: Forense, 1977, p. 447 apud STRECK, Lenio Luiz; NUNES, Dierle; CUNHA, Leonardo Carneiro da (Orgs.); FREIRE, Alexandre (Coord. Exec.) Comentários ao Código de Processo Civil, 2. ed. São Paulo: Saraiva, 2017, p. 522.

CAPPELETTI, Mauro; BRYANT, Garth. Acesso à justiça. Porto Alegre: Frabris, 1988 (Trad. Hellen Gracie Northfleet).

CNJ. Conselho Nacional de Justiça. Diagnóstico da atuaçáo dos conselhos profissionais na cobrança da dívida ativa. Brasília: $\mathrm{CNJ}$, 2019a.

. Conselho Nacional de Justiça. Justiça em Números. Brasília: CNJ, $2019 b$.

DELFINO, Lucio. Capítulo VIII: Da revelia. In: STRECK, lenio Luiz; NUNES, Dierle; CUNHA, Leonardo Carneiro da (Orgs.); FREIRE, Alexandre (Coord. Exec.) Comentários ao Código de Processo Civil, 2. ed. São Paulo: Saraiva, 2017.

DIDIER JÚNIOR, Fredie. Curso de direito processual civil: introduçáo ao direito processual civil, parte geral e processo de conhecimento, 19. ed. Salvador: Jus Podivm, 2017.

DIDIER JÚNIOR, Fredie; CUNHA, Leonardo Carneiro da. Curso de direito processual civil: o processo civil nos tribunais, recursos, açôes de competência originária de tribunal e querela nullitatis, incidentes de competência originária de tribunal, 13. ed., vol. 3, Salvador: Juspodivm, 2016.

ESTEVES, Diogo; SILVA, Franklyn Roger Alves. A curadoria especial no novo código de processo civil. In SOUSA, José Augusto Garcia. Repercussóes do novo CPC: Defen- 
soria Pública. Salvador: Juspodivm, 2015.

2018.

Princípios institucionais da Defensoria Pública, 3 ed. Rio de Janeiro: Forense,

GRECO, Leonardo. Instituiçóes de processo civil [Recurso eletrônico], vol. 1, 5. ed. Rio de Janeiro: Forense, 2015.

IPEA. Instituto de Pesquisa Econômica Aplicada. Custo Unitário do Processo de Execuçáo Fiscal na Justiça Federal: Relatório de Pesquisa. Brasília: Ipea, 2011.

MOURA; CUSTÓRIO; SILVA; CASTRO. Mapa da Defensoria Pública no Brasil, 1. ed. Instituto de Pesquisa Econômica Aplicada. Brasília: Ipea, 2013.

JALES, Túlio de Medeiros. Novo código de processo civil e fundamentação da decisão judicial: horizontes argumentativo e hermenêutico. Revista Direito e Liberdade - ESMARN, vol. 17, n. 3, p. 261-301, set-dez. 2015.

MARINONI, Luiz Guilherme; ARENHART, Sérgio Cruz; MITIDIERO, Daniel. Novo curso de processo civil: tutela dos direitos mediante procedimento comum, vol. 2. Revista dos Tribunais: São Paulo, 2015.

MARSAN, Gabriel Ignacio Anitua. A defensoria pública como garantia de acesso à justiça. Revista da Defensoria Pública do Distrito Federal, Brasília, v. 1, n. 1, 2019, p. 19-27.

MARTINS, Leonardo; DIMOULIS, Dimitri. Teoria geral dos direitos fundamentais, 5. ed. São Paulo: Atlas, 2014.

MONTENEGRO FILHO, Misael. Novo código de processo civil comentado, 2. ed. São Paulo: Atlas, 2016.

NOGUEIRA, Pedro Henrique. Título II: da comunicação dos atos processuais. In: STRECK, lenio Luiz; NUNES, Dierle; CUNHA, Leonardo Carneiro da (Orgs.); FREIRE, Alexandre (Coord. Exec.) Comentários ao Código de Processo Civil, 2. ed. São Paulo: Saraiva, 2017.

NEVES, Daniel Amorim Assumpção. Manual de direito processual civil, 11. ed. Salvador: Ed. Juspodivm, 2019.

NÚNEZZ, Lucas Pahl Schaan. Uma análise racional do benefício da gratuidade judiciária e dos pressupostos para a sua concessáo. Revista Eletrônica de Direito Processual, ano 12, vol 19, n.3. Rio de Janeiro: UERJ, 2018 (set./dez).

OLIVEIRA, Rafael Alexandria de. Benefício da justiça, p. 320. In: Teresa Arruda Alvim Wambier, Fredie Didier Jr., Eduardo Talamini, Bruno Dantas, Breves comentários ao novo Código de Processo Civil, São Paulo: Revista dos Tribunais, 2015. 
REBELLO, Ana Beatriz F. O problema do rol taxativo do 1015: há uma soluçáo no CPC? Pensamos que sim!, 22 maio 2017. Disponível em: https://processualistas.jusbrasil.com.br/artigos/460956892/o-problema-do-rol-taxativo-do-1015-ha-uma-solucao-no-cpc. Acesso em 07 nov. 2019.

ROCHA, Amélia Soares. Defensoria Pública: fundamentos, organização e funcionamento. São Paulo: Atlas, 2013.

SICA, Heitor Vitor Mendonça. Da contestação, p 840. In: Teresa Arruda Alvim Wambier, Fredie Didier Jr., Eduardo Talamini, Bruno Dantas, Breves comentários ao novo Código de Processo Civil, São Paulo: Revista dos Tribunais, 2015.

SILVA, Péricles Batista da. Defensoria Pública e curadoria especial no Superior Tribunal de Justiça: a obrigatoriedade de recolhimento das custas de preparo como requisito de admissibilidade do recurso especial. Revista da Defensoria Pública do Distrito Federal, Brasília, v. 1, n. 1, 2019, p. 123/136.123.

STF. Superior Tribunal Federal. A Constituição e o Supremo, 4. ed. Brasília: Secretaria de Documentação, 2011. p. 313.

TAMANAHA, Brian Z. On the rule of law: history, politics, theory. Cambridge University Press, New York, 2004.

TARTUCE, Fernanda. Igualdade e vulnerabilidade no processo civil. Rio de Janeiro: Forense, 2012.

THEODORO JÚNIOR, Humberto. Curso de direito processual civil, vol. 1, 59. ed. Rio de janeiro: Forense, 2019.

WAMBIER, Luiz Rodrigues; TALAMINI, Eduardo. Curso avançado de processo civil: cognição jurisdicional (processo comum de conhecimento e tutela provisória), vol 2. 16. ed. São Paulo: Revista dos Tribunais, 2016. 